\title{
Comparison of bacterial community structures in two systems of a sewage treatment plant using PCR-DGGE analysis
}

\author{
Abd El-Latif Hesham ${ }^{1,2}$, Rong Qi ${ }^{1}$, MinYang ${ }^{1, *}$ \\ 1. State Key Laboratory of Environmental Aquatic Chemistry, Research Center for Eco-Environmental Sciences, \\ Chinese Academy of Sciences, Beijing 100085, China. E-mail: yangmin@rcees.ac.cn \\ 2. Genetics Department, Faculty of Agriculture, Assiut University, Assiut, Egypt \\ Received 30 January 2011; revised 11 May 2011; accepted 13 May 2011
}

\begin{abstract}
The combination of PCR amplification of 16S rRNA genes with denaturing gradient gel electrophoresis (DGGE) analysis was used to reveal the compositions and dynamics of bacterial communities in a sewage treatment plant with two systems, i.e., an anoxicanaerobic-aerobic system (inverted A2O) and an anaerobic-anoxic-aerobic one (conventional A2O) over a period from February to July 2009, during which both systems experienced serious sludge bulking problems. The DGGE patterns showed that there were many common bands in both systems, suggesting the high similarity of bacterial communities of the two systems. Meanwhile, the moving window correlation analysis showed that the two systems experienced different microbial community structure changes during the period, which might be related with the different situations of the occurrence and disappearance of sludge bulking, as being reflected by sludge volume index (SVI) values. Major bands of DGGE patterns of sludge samples were further sequenced. Phylogenetic affiliation indicated that the majority of the sequences obtained were affiliated with Actinobacteria, Firmicutes, Bacteroidetes/Chlorobi group and $\alpha$ - and $\beta$-Proteobacteria. Two sequences showed high similarities to typical filamentous bacteria Microthrix parvicella and Nostocoida limicola I, indicating that these bacterial species have been involved in the sludge bulking problems.
\end{abstract}

Key words: PCR-DGGE; bacterial community; activated sludge; sludge bulking; sewage treatment plant DOI: $10.1016 / \mathrm{S} 1001-0742(10) 60647-\mathrm{X}$

Citation: Hesham A E, Qi R, Yang M, 2011. Comparison of bacterial community structures in two systems of a sewage treatment plant using PCR-DGGE analysis. Journal of Environmental Sciences, 23(12): 2049-2054

\section{Introduction}

Biological treatment of municipal and industrial wastewaters has been widely used in the world because of the low cost. A through understanding of the microbial composition of activated sludge is important for understanding the mechanism of biological treatment processes, particularly for abating problems like sludge bulking or foaming (Kumari et al., 2009). Knowledge of microbial composition of activated sludge has been greatly extended by molecular studies based on the analysis of $16 \mathrm{~S}$ rRNA gene sequences. The recently developed molecular biological techniques such as 16S rDNA clone library (McGarvey et al., 2004; Otawa et al., 2006), ribosomal intergenic spacer analysis (RISA) (Yu and Mohn, 2001; Baker et al., 2003), 16S-restriction fragment length polymorphism (16S-RFLP) (Baker et al., 2003; Gilbride and Fulthorpe, 2004), have made it possible to look into microbial ecology in wastewater treatment systems without culturing microbial strains. Compared to other methods, PCR-denaturing gradient gel electrophoresis (DGGE) is

\footnotetext{
* Corresponding author. E-mail: yangmin@ rcees.ac.cn
}

cheap and fast, and could be used to compare microbial community structure changes of different systems (Liu et al., 2002; Casserly and Erijman, 2003; Kaksonen et al., 2003; Rowan et al., 2003). Studies concerning bacterial composition and dynamic in wastewater using DGGEbased approaches have been performed for activated sludge (Boon et al., 2002; Ibekwe et al., 2003; Gilbride et al., 2006; Liu et al., 2007a, 2007b).

With the help of these molecular techniques, it is now clear that the phylum Proteobacteria was generally dominant in activated sludge of municipal wastewater treatment plants (MWTPs) with $\beta$-Proteobacteria being the most frequently observed, followed by the phyla Bacteroidetes and Actinobacteria. It is known that bacterial community structures in different MWTPs are quite different because of the differences in wastewater compositions and operational conditions. It is not clear, however, how different it would be for two different processes treating the same sewage.

Thus, we compared bacterial community structures in two systems, a conventional A2O (anaerobic-anoxicaerobic) process and an inverted $\mathrm{A} 2 \mathrm{O}$ (anoxic-anaerobicaerobic) one, in the same MWTP located in a north China 
city. 16S PCR-DGGE analysis was used to obtain patterns of bacterial community and trace the change of bacterial community in both systems over a period from February to July, during which significant sludge bulking was found in both systems, and then predominant bacteria were identified by cloning and sequencing of the bands excised from DGGE gels. The results could help to understand the mechanism of sludge bulking.

\section{Material and methods}

\subsection{Sampling, physical and chemical characterization}

Sludge samples were collected from the two processes (inverted and conventional A2O) of a sewage treatment plant in a north China city and kept at $-20^{\circ} \mathrm{C}$ until used for DNA extraction. Sampling was performed monthly from February to July 2009. Sampling in the two processes starting from February to July 2009, resulted in a total of 12 samples (6 samples per process). The chemical oxygen demand (COD), biochemical oxygen demand (BOD5), suspended solids (SS), temperature and dissolved oxygen (DO) were determined by standard methods (Clescerl et al., 1998).

\subsection{Nucleic acid extraction and PCR amplification of 16S rRNA gene}

DNA was extracted using a soil DNA extraction kit (fast DNA spin kit for soil, France) following the manufacturer's instructions. The extracted products were visualized on $1 \%$ agarose gel. Extracted DNA was amplified in a Thermal Cycler using 341f/926r primer set or 341f-GC/ 926r primer set (341f: 5'-CCT ACG GGA GGC AGC AG-3'; 341f-GC: GC-clamp with 5'-CGC CCG CCG CGC GCG GCG GGC GGG GCG GGG GCA CGG GGG G-3' attached on the 5' end of 341f, 926r: 5'-CCG TCA ATT CCT TTG AGT TT-3') (Muyzer et al., 1996; Nagashima et al., 2003; Gulez and de los Reyes, 2009). Hot-start PCR was used to minimize nonspecific binding of primers to nontarget DNA as described by Muyzer et al. (1993) in which the TaKaRa rTaq DNA polymerase (Takara, Dalian, China) was added at $80^{\circ} \mathrm{C}$ and $5 \mathrm{~min}$ into the first denaturing period. This was followed by 29 cycles of $1 \mathrm{~min}$ annealing at $62^{\circ} \mathrm{C}$ and $3 \mathrm{~min}$ extension at $72^{\circ} \mathrm{C}$ and 1 min denaturing at $94^{\circ} \mathrm{C}$. The amplification was completed after a final extension at $72^{\circ} \mathrm{C}$ for $30 \mathrm{~min}$. The amplified products were visualized on $1 \%$ agarose gel stained with ethidium bromide (final concentration of $10 \mathrm{mg} / \mathrm{mL})$.

\subsection{Denaturing gradient gel electrophoresis (DGGE) and sequencing}

DGGE was performed using a Bio-Rad DCode system (Bio-Rad, USA), using a $6 \%$ polyacrylamide gel with $25 \%$ to $60 \%$ denaturing concentrations in $1 \times$ TAE buffer as previously described (Muyzer et al., 1996; Gulez and de los Reyes, 2009; Bio-Rad Manual, USA). Electrophoresis was performed at $80 \mathrm{~V}$ and $60^{\circ} \mathrm{C}$ for $17 \mathrm{hr}$. The gel was stained for $15 \mathrm{~min}$ with ethidium bromide after electrophoresis, and visualized with a UV transilluminator table using a Gel Documentation System (Bio-Rad Laboratories-Segrate, Milan, Italy). Individual band patterns were compared with each other using the pairwise similarity coefficient of Dice $(S)$ as follows:

$S=2 j /(a+b)$

where, $a$ is the number of DGGE bands in pattern $1, b$ is the number of bands in pattern 2 and $j$ is the number of common bands. Then cluster analysis of band patterns was performed using the unweighted-pair group method using average linkages (UPGMA).

By plotting the correlation coefficients between day $x$ and day $(x+30)$ for each process against the time, graphical representations of the evolution of stability (moving window) over time for bacterial communities in the two systems were obtained (Wittebolle et al., 2008; Marzorati et al., 2008).

\subsection{Cloning of excised DGGE bands, sequencing and phylogenetic analysis}

Bands of interest were excised from the DGGE gel using syringe needles, suspended overnight in $12.5 \mu \mathrm{L}$ sterile water and PCR amplified using 341f and 926r primers. The PCR products were purified using an agarose gel DNA purification kit (Takara Co., Dalian, China). The amplified $16 \mathrm{~S}$ rRNA gene fragments were cloned into the TOPO TA cloning vector PCR2.1, and then TOP10 chemically competent Escherichia coli was transformed with the plasmids according to manufacture's instructions (Invitrogen, Shanghai, China). Transformants were selected by bluewhite selection on Luria-Bertani agar plates containing ampicillin $(100 \mu \mathrm{g} / \mathrm{mL})$. Cloned inserts were amplified from lysed colonies by PCR with plasmid-vector specific primers M13F (5'-GTA AAA CGA CGG CCA G-3') and M13R (5'-CAG GAA ACA GCT ATG AC-3'). Clones were sequenced with an $\mathrm{ABI} 3730$ automated sequencer (Invitrogen, Shanghai, China). The sequences obtained were checked for chimeras using Chimera Detection in the Ribosomal Database Project (http://rdp8.cme.msu.edu) and compared with sequences in the BLAST/NCBI database (http://www.ncbi.nlm.nih.gov/BLAST) to determine the nearest matches. Phylogenetic trees were constructed using MEGA version 4.0 by the neighborjoining algorithm, and the Jukes-Cantor distance estimation method with bootstrap analyses for 1000 replicates was performed.

\subsection{Nucleotide sequence accession numbers}

The partial 16S rRNA gene sequences that were determined in this study have been deposited in the GenBank nucleotide sequence database under accession numbers HQ730880 to HQ730890.

\section{Results and discussion}

\subsection{Performance of the two systems}

The two processes demonstrated almost identical performance. The average of the removals of COD, BOD and SS 
during the monitored period were $95.7 \%, 96.5 \%, 92.6 \%$ for the inverted A2O system and $96.0 \%, 97.3 \%, 93.9 \%$ for the conventional one, respectively.

\subsection{DGGE analysis of the diversity of bacterial commu- nity}

In this study, the changes of bacterial communities of the two systems were elucidated by the DGGE phylotype. As shown in Fig. 1, a total of 15 bright bands were detected in DGGE gel (weak bands were discarded) which were common in the two processes, indicating that there were high similarities of the populations of bacteria between them. DGGE bands 3, 7, 8, 9 and 15 were detected in all profiles, and several band positions were unique for some months (e.g., bands 4, 5, 6, 10, 11, 12, 13, and 14). Band 13 appeared only in May to July of the two processes, while bands 4, 5, 6 and 10 appeared in the last three months (May to July). These differences indicated that some variance of bacterial community compositions existed during the period.

Furthermore, DGGE patterns were compared with one

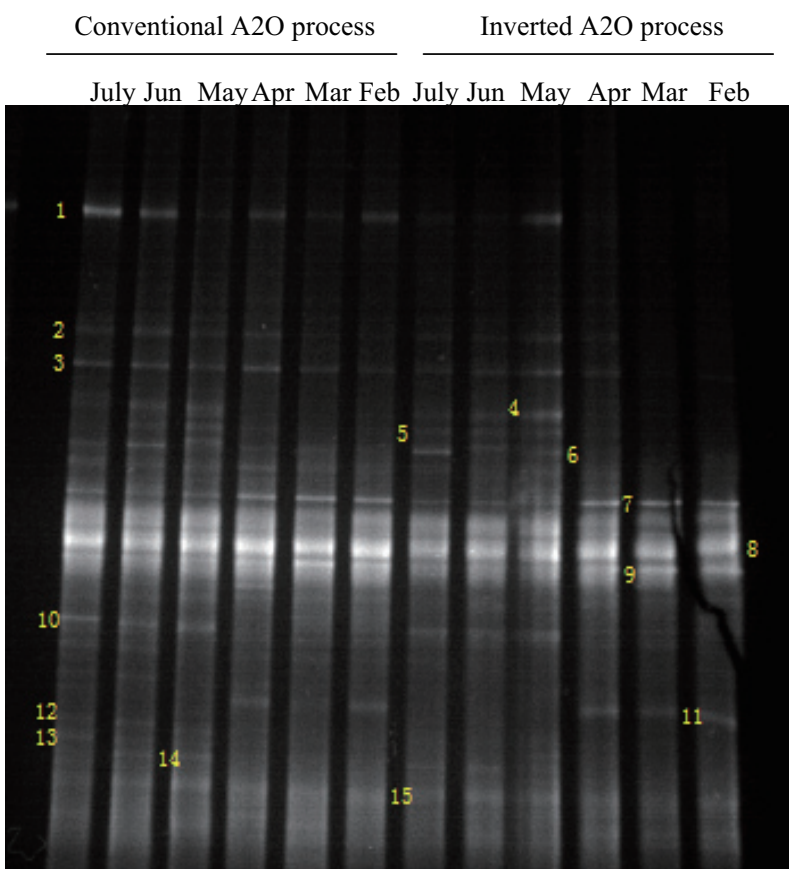

Fig. 1 DGGE band profiles of 16S rDNA amplified using the total genomic DNA extracted from sludge collected from two systems (inverted and conventional $\mathrm{A} 2 \mathrm{O}$ process) of a sewage plant from February to July 2009 . another by pairwise similarity coefficient of dice $(S)$, which ranged from 0.417 to 1.000 . Cluster analysis demonstrated that band patterns of samples of June to July in conventional A2O process were closely related to each other (Fig. 2), with $S$ values of 0.854 , and the patterns of samples of February and March were also similar to each other ( $S$ value, 0.722). Meanwhile, the band patterns of samples of April in inverted A2O process showed higher similarities to those of samples of February, March and June ( $S$ values of $0.735-0.862$ ), while the band pattern of the sample of May was quite different from all the others with $S$ values of 0.444 to 0.498 . These results also confirm that bacterial communities in both treatment systems exhibited some changes.

The evolution of the similarity over time is depicted using the moving window correlation approach (Fig. 3). The similarity of bacterial community in conventional A2O process became relatively stable after reaching the lowest value of $55 \%$. The changes of bacterial community similarity in inverted $\mathrm{A} 2 \mathrm{O}$ process were significant with the values decreased to $49 \%$ firstly and increased to $73 \%$ finally. These results indicated that bacterial communities in the two treatment systems experienced quite different variance.

The above results of the evolution of stability for bacterial community and cluster analysis of DGGE patterns in two systems might be linked with that of sludge volume index (SVI) as shown in Fig. 4. The SVI values of inverted A2O experienced significantly large variance compared

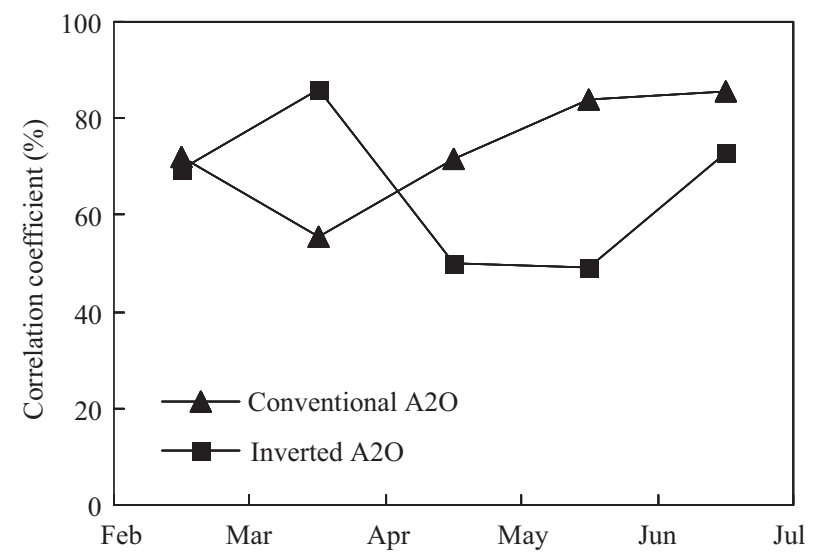

Fig. 3 Moving window correlation for conventional and inverted A2O. Variability between day $x$ and day $(x+30)$ was calculated from DGGE patterns of bacterial community.
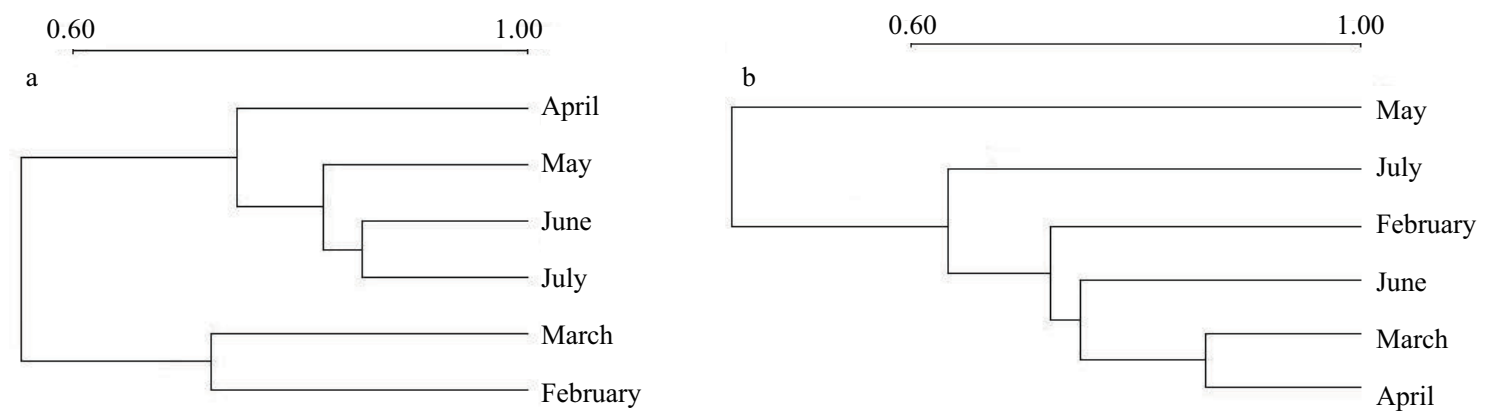

Fig. 2 Cluster analysis of DGGE band patterns using Quantity One software. (a) conventional A2O process; (b) inverted A2O process. 

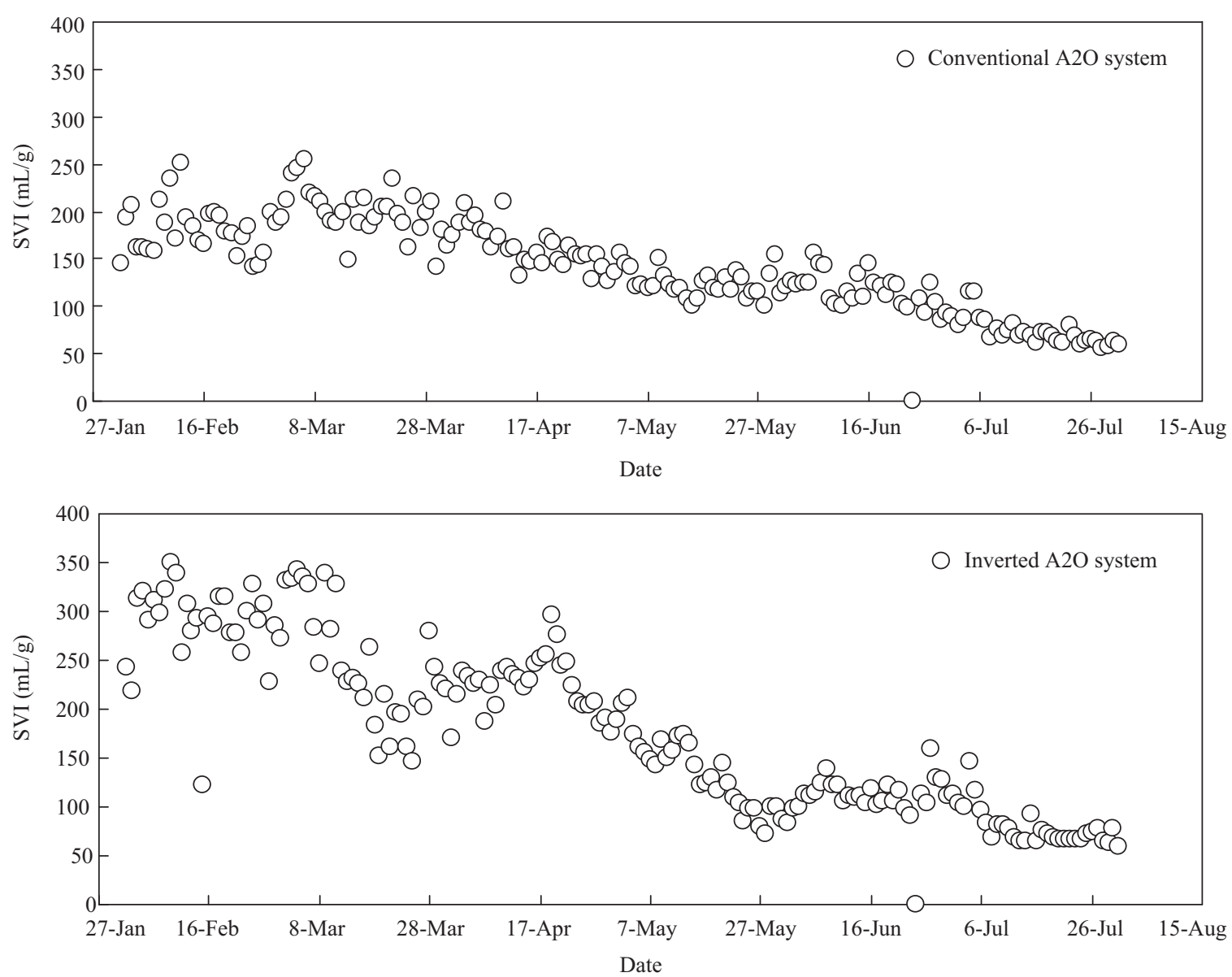

Fig. 4 SVI values in the conventional and inverted A2O process during different months (Feb- Jul).

to that of conventional A2O during the whole sampling period. The SVI values decreased from approximately 350 $\mathrm{mL} / \mathrm{g}$ in February to $60 \mathrm{~mL} / \mathrm{g}$ in July in the inverted A2O system, and some obvious increase of the value was even observed in April and June, possibly resulting in the comparably low similarity of bacterial community with the moving window analysis. These results were also in accordance with the cluster analysis of DGGE patterns of the inverted $\mathrm{A} 2 \mathrm{O}$, which indicated that band patterns of May and July (both SVI values below $100 \mathrm{~mL} / \mathrm{g}$ ) were obviously different from those of other months (all with SVI above $100 \mathrm{~mL} / \mathrm{g}$ ). Meanwhile, the relatively stable decrease of SVI values in conventional A2O from 250 to $60 \mathrm{~mL} / \mathrm{g}$ might be the reason of the stable growth of similarity of bacterial community with the moving window analysis. The similar band patterns between February and
March might be the result of higher SVI values of around $200 \mathrm{~mL} / \mathrm{g}$ compared to those below $150 \mathrm{~mL} / \mathrm{g}$ during April to July.

\subsection{Phylogenetic analysis}

According to the principle of DGGE, the total DNAs with the same length but different sequences could be separated. Each band corresponded approximately to a dominant microbial community and more bands suggested higher diversity. In this study, 11 sequences (corresponding bands are indicated in Fig. 1) were obtained from the two systems, and were subsequently used for comparative analysis. Each sequence was submitted to a BLAST search and results of their closest relative are shown in Table 1.

As shown in Fig. 5, the sequences of bands 6 and 10 were grouped into $\beta$-Proteobacteria and affiliated

Table 1 Phylogenetic sequence affiliation and similarity to the closest relative of amplified 16S rRNA gene sequences excised from DGGE gels

\begin{tabular}{|c|c|c|c|c|}
\hline Band number & Similarity & Organism & Phylogenetic affiliation & Accession number \\
\hline 1 & $98 \%$ & Uncultured Chlorobi bacterium & Bacteroidetes & GU123155 \\
\hline 2 & $92 \%$ & Uncultured Sphingobacteriaceae bacterium & Bacteroidetes & GU257878 \\
\hline 3 & $99 \%$ & Novosphingobium mathurense & $\alpha$-Proteobacteria & FM164634 \\
\hline 4 & $99 \%$ & Uncultured Chlorobi bacterium & Bacteroidetes & FJ484824 \\
\hline 6 & $99 \%$ & Uncultured $\beta$-Protobacteria & $\beta$-Protobacteria & FJ660557 \\
\hline 7 & $99 \%$ & Uncultured Firmicutes bacterium & Firmicutes & CU918169 \\
\hline 8 & $99 \%$ & Uncultured Firmicutes bacterium & Firmicutes & CU926587 \\
\hline 9 & $98 \%$ & Sphingopyxis sp. & $\alpha$-Proteobacteria & EU440980 \\
\hline 10 & $99 \%$ & Simplicispira sp. & $\beta$-Protobacteria & AM236310 \\
\hline 11 & $98 \%$ & Nostocoida limicola I & Actinobacteria & AF255736 \\
\hline 15 & $99 \%$ & Microthrix parvicella & Actinobacteria & DQ147285 \\
\hline
\end{tabular}




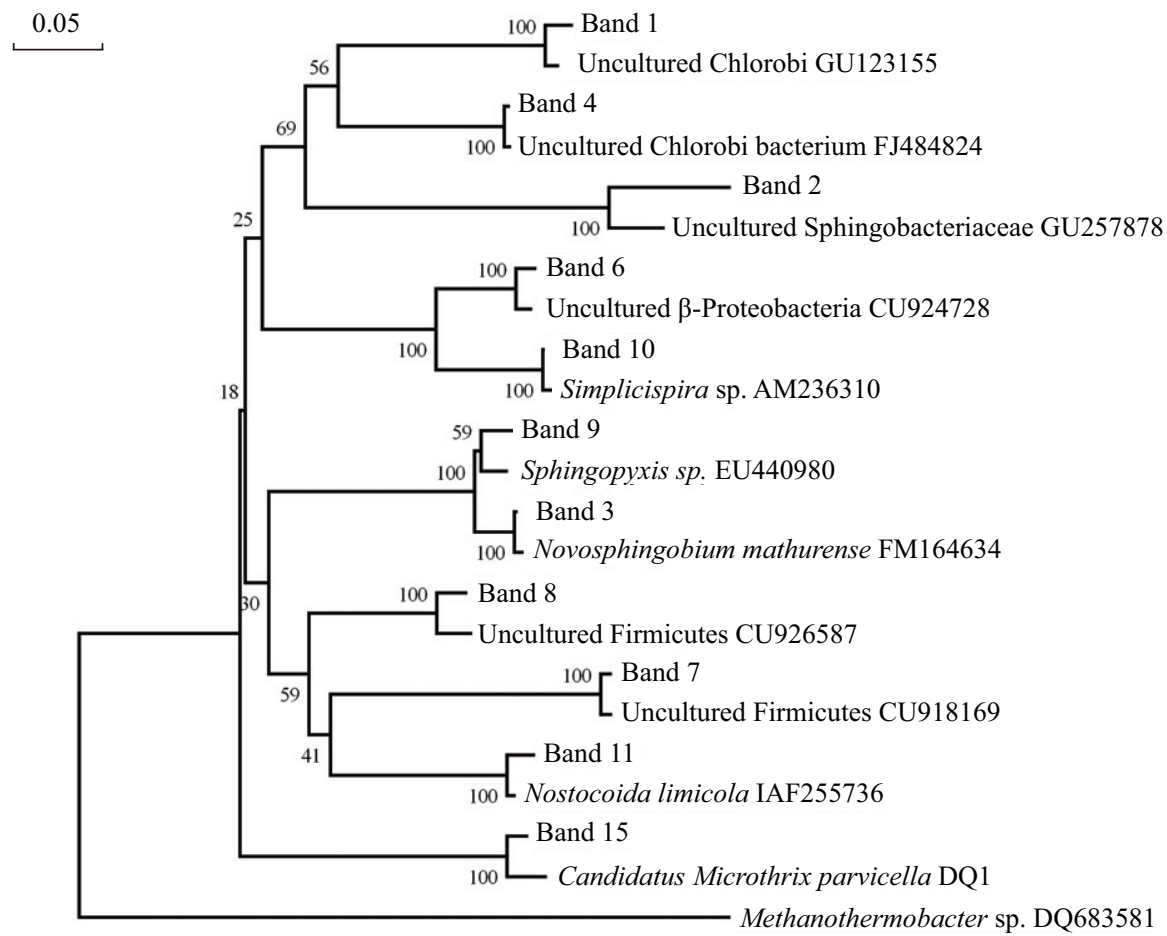

Fig. 5 Phylogenetic tree based on 16S rRNA gene sequences which were derived from DGGE patterns of the inverted and conventional A2O process.

with uncultured $\beta$-Protobacteria and Simplicispira sp. which have been used to remove inorganic nutrients from wastewater and are becoming more important for reducing eutrophication within lakes ( $\mathrm{Lu}$ et al., 2007). Meanwhile, the sequences of bands 3 and 9 were grouped into $\alpha$-Proteobacteria and related with Novosphingobium mathurensis and Sphingopyxis sp., respectively. Members of $\alpha$-Proteobacteria are known for degradation of chlorophenol and dichlorophenoxy acetic acid, thiophene2-carboxylate metabolization of phenanthrene and sulphur containing substrates, polycyclic aromatic and xenobiotics degrader (Rani et al., 2008). The sequences of bands 2, 7 and 8 were affiliated to Sphingobacteriaceae and Firmicutes, respectively. The organisms related with the phyla Proteobacteria, Bacteroidetes, and Firmicutes were usually observed in active sludge processes and are very diverse (Rani et al., 2008; Moura et al., 2009) with many organisms involved in pollutant degradation, which suggest the importance of such communities for wastewater treatment. The sequences of bands 1 and 4 were closely related to filamentous green sulfur bacteria Chlorobi which belongs to Bacteroidetes/Chlorobi group. This group has previously been detected in wastewater environments (Valle et al., 2004). These bacteria were commonly occurring in domestic wastewater systems. Similar results were obtained in 16S rDNA libraries from activated sludge communities (Jiang et al., 2008). Finally, the sequences of bands 11 and 15 showed high similarities to N. limicola I and Microthrix parvicella, respectively, both of which belonged to Actinobacteria and were typical filamentous bacteria responsible for sludge bulking (Levantesi et al., 2004; Kaetzke el al., 2005; Kumari et al., 2009). Band 11 existed mainly during the period from February to April, which was in accordance with the changes of SVI values. So at least $N$. limicola I might be related with sludge bulking to some extent.

\section{Conclusions}

The PCR-DGGE method applied here has provided insights regarding the structures and dynamics over six months of bacterial communities from a sewage plant with both inverted and conventional $\mathrm{A} 2 \mathrm{O}$ processes during a serious sludge bulking period. The results indicated that bacterial community structures were similar between the two systems and changed obviously during the period. Similar bacterial compositions could be the fundamental reason for the similar operational efficiency of these two systems. Different sludge bulking processes being reflected by SVI values might result in the distinct evolutional processes of bacterial communities in the two systems. Although most of the identified bacterial sequences belonged to normal bacterial groups in activated sludge systems, some filamentous bacteria $M$. parvicella and $N$. limicola I related sequences possibly accounted for the appearance of sludge bulking in the systems.

\section{Acknowledgment}

This work was supported by the National Research Foundation, China (No. 20921140094), the Chinese Academy of Sciences, Knowledge innovation Project (No. KSCX2-YW-G-054, KZCX2-YW-JC407) and CASTWAS Postdoctoral Fellowships 2009. 


\section{References}

Baker C J O, Fulthorpe R R, Gilbride K A, 2003. An assessment of variability of pulp mill wastewater treatment system bacterial communities using molecular methods. Water Quality Research Journal of Canada, 38(2): 227-242.

Boon N, Windt W, Verstraet W, Top E M, 2002. Evaluation of nested PCR-DGGE with group-specific 16S rRNA primers for the analysis of bacterial communities from different wastewater treatment plants. FEMS Microbiology Ecology, 39(2): 101-112.

Casserly C, Erijman L, 2003. Molecular monitoring of microbial diversity in an UASB reactor. International Biodeterioration and Biodegradation, 52(1): 7-12.

Clescerl L S, Greenberg A E, Eaton A D, 1998. Standard Methods for the Examination of Water and Wastewater. APHA, AWWA, WEF, Washington, USA .

Gilbride K A, Fulthorpe R R, 2004. A survey of the composition and diversity of bacterial populations in bleached kraft pulpmill wastewater secondary treatment systems. Canadian Journal of Microbiology, 50(8): 633-644.

Gilbride K A, Frigon D, Cesnik A, Gawat J, Fulthorpe R R, 2006. Effect of chemical and physical parameters on a pulp mill biotreatment bacterial community. Water Research, 40(4): $775-787$.

Gulez G, de los Reyes F L III, 2009. Multiple approaches to assess filamentous bacterial growth in activated sludge under different carbon source conditions. Journal of Applied Microbiology, 106(2): 682-691.

Ibekwe A M, Grieve C M, Lyon S R, 2003. Characterization of microbial communities and composition in constructed dairy wetland wastewater effluent. Applied and Environmental Microbiology, 69(9): 5060-5069.

Jiang X, Ma M C, Li J, Lu A H, Zhong Z S, 2008. Bacterial diversity of active sludge in wastewater treatment plant. Earth Science Frontiers, 15(6): 163-168.

Kaetzke A, Jentzsch D, Eschrich K, 2005. Quantification of Microthrix parvicella in activated sludge bacterial communities by real-time PCR. Letters in Applied Microbiology, 40(3): 207-211.

Kaksonen A H, Plumb J J, Franzmann P D, Puhakka J A, 2003. Simple organic electron donors support diverse sulfatereducing communities in fluidized-bed reactors treating acidic metal- and sulfate-containing wastewater. FEMS Microbiology Ecology, 47(3): 279-289.

Kumari S K S, Marrengane Z, Bux F, 2009. Application of quantitative RT-PCR to determine the distribution of Microthrix parvicella in full-scale activated sludge treatment systems. Applied Microbiology and Biotechnology, 83(6): 1135-1141.

Levantesi C, Beimfohr C, Geurkink B, Rossetti S, Thelen K, Krooneman J et al., 2004. Filamentous alphaproteobacteria associated with bulking in industrial wastewater treatment plants. Systematic and Applied Microbiology, 27(6): 716727.

Liu W T, Huang C L, Hu J Y, Song L F, Ong S L, Ng W J, 2002. Denaturing gradient gel electrophoresis polymorphism for rapid 16S rDNA clone screening and microbial diversity study. Journal of Bioscience and Bioengineering, 93(1): 101103.

Liu X C, Yang M, Zhang Y, Yang X P, Gan Y P, 2007b. Microbial community comparison of different biological processes for treating the same sewage. World Journal of Microbiology and Biotechnology, 23(1): 135-143.

Liu X C, Zhang Y, Yang M, Wang Z J, Lv W Z, 2007a.
Analysis of bacterial community structures in two sewage treatment plants with different sludge properties and treatment performance by nested PCR-DGGE method. Journal of Environmental Sciences, 19(1): 60-66.

Lu S P, Ryu S H, Chung B S, Chung Y R, Park W, Jeon P W, 2007. Simplicispira limi sp. nov., isolated from activated sludge. International Journal of Systematic and Evolutionary Microbiology, 57(1): 31-34.

Marzorati M, Wittebolle L, Boon N, Daffonchio D, Verstraete W, 2008. How to get more out of molecular fingerprints: practical tools for microbial ecology. Environmental Microbiology, 10(6): 1571-1581.

McGarvey J A, Miller W G, Sanchez S, Stanker L, 2004. Identification of bacterial populations in dairy wastewaters by use of $16 \mathrm{~S}$ rRNA gene sequences and other genetic markers. Applied and Environmental Microbiology, 70(7): 4267-4275.

Moura A, Tacão M, Henriques I, Dias J, Ferreira P, Correia A, 2009. Characterization of bacterial diversity in two aerated lagoons of a wastewater treatment plant using PCR-DGGE analysis. Microbiological Research, 164(5): 560-569.

Muyzer G, de Waal E C, Uitterlinden A G, 1993. Profiling of complex microbial populations by denaturing gradient gel electrophoresis analysis of PCR reaction-amplified genes coding for 16S rRNA. Applied and Environmental Microbiology, 59(3): 695-700.

Muyzer G, Hottentraeger S, Teske A, Wawer C, 1996. Denaturing gradient gel electrophoresis of PCR amplified 16S rDNA A new molecular approach to analyze the genetic diversity of mixed microbial communities. In: Molecular Microbial Ecology Manual. Kluwer Academic Publishers, the Netherlands. $1-23$.

Nagashima K, Hisada T, Sato M, Mochizuki J, 2003. Application of new primer-enzyme combinations to terminal restriction fragment length polymorphism profiling of bacterial populations in human feces. Applied and Environmental Microbiology, 69(2): 1251-1262.

Otawa K, Asano R, Oba Y, Sasaki T, Kawamura E, Koyama F et al., 2006. Molecular analysis of ammonia-oxidizing bacteria community in intermittent aeration sequencing batch reactors used for animal wastewater treatment. Environmental Microbiology, 8(11): 1985-1996.

Rani A, Porwal S, Sharma R, Kapley A, Purohit H J, Kalia V $\mathrm{C}, 2008$. Assessment of microbial diversity in effluent treatment plants by culture dependent and culture independent approaches. Bioresource Technology, 99(15): 7098-7107.

Rowan A K, Snape J R, Fearnside D, Barer M R, Curtis T P, Head I M, 2003. Composition and diversity of ammonia-oxidising bacterial communities in wastewater treatment reactors of different design treating identical wastewater. FEMS Microbiology Ecology, 43(2): 195-206.

Wittebolle L, Vervaeren H, Verstraete W, Boon N, 2008. Quantifying community dynamics of nitrifiers in functionally stable reactors. Applied and Environmental Microbiology, 74(1), 286-293.

Valle A, Bailey M J, Whiteley A S, Manefield M, 2004. N-acylL-homoserine lactones (AHLs) affect microbial community composition and function in activated sludge. Environmental Microbiology, 6(4): 424-433.

Yu Z T, Mohn W W, 2001. Bacterial diversity and community structure in an aerated lagoon revealed by ribosomal intergenic spacer analyses and 16S ribosomal DNA sequencing. Applied and Environmental Microbiology, 67(4): 15651574. 